\title{
Examining Catherine of Siena's controversial discernments about papal politics
}

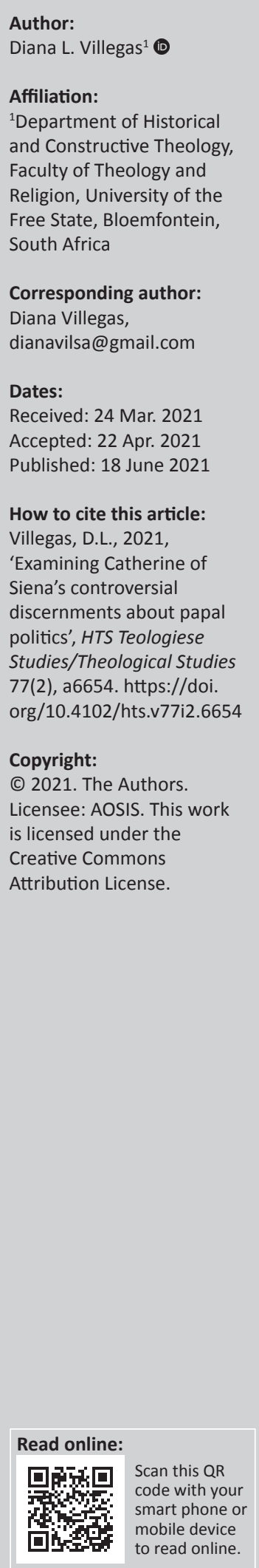

Catherine of Siena (1347-1380) contributed important wisdom to Christian spirituality on discernment, yet her own discernment regarding her engagement in papal politics has not been studied. From the perspective of Christian spirituality studies, this article examines the critical text of her letters in relationship with historical events to offer a description of the instances where Catherine's discernment differed from that of others committed to a spiritual journey and to seeking the good of the church. Catherine's view of God's will regarding the papal interdict of Florence controverted that of several ecclesial leaders more likely to be right. Catherine's advocacy for the crusade differed from the advice Birgitta of Sweden gave Gregory XI, advice corroborated by history. Two of Catherine's spiritual mentors made decisions they discerned to be right regarding missions on which they were sent by the pope, whereas Catherine reproached them for these choices. Furthermore, Catherine was certain that the election of Urban VI had been blessed by God, whereas another saint considered Clement VII to be the true pope. The above analysis is followed by an examination of influences on Catherine's experience of seeking and implementing God's will, seeking to account for the divergence between her discernment and that of others. In conclusion, while Catherine was confident in her union with God and, therefore, God's guidance, she was also influenced by her unbending beliefs about truth and by the manner these beliefs were conditioned by her personality and sociocultural context.

Contribution: This article contributes to scholarship in Christian spirituality on the spirituality of Catherine of Siena and on discernment, studying Catherine of Siena's discernment regarding papal politics where she differed from others whose discernment can be interpreted as more likely to be congruent with God's will. The reasons for her controversial discernment are explored.

Keywords: discernment; Catherine of Siena and discernment; discernment and beliefs; Catherine of Siena letters; finding God's will; female mystics; later Middle Ages.

\section{Introduction}

Catherine of Siena's teaching on discernment, ${ }^{1}$ an aspect of spiritual practice on which she offered historically significant wisdom, has been thematised before and is summarised here. This article from the perspective of scholarship in Christian spirituality examines instances where Catherine's discernment diverged from that of others considered holy and wise and where their discernments were more likely to be correct than hers. ${ }^{2}$ The question is then explored: given Catherine's reputation for holiness and commitment to seeking God's will for the good of the church, how can one interpret her apparently incorrect discernments? I propose that Catherine's paramount beliefs ${ }^{3}$ held in an unbending manner conditioned her controversial discernments. Her personality and sociocultural context further influenced her interpretation of God's will. This innovative analysis is based on examination of relevant letters in dialogue with pertinent historical material; it discloses a new aspect of Catherine's practice of discernment, one that can also offer wisdom for today. 1.This spiritual practice described in the history of spirituality since patristic times involves sorting out God's guidance and will. For a
detailed treatment of discernment, see Mclntosh (2004).
2.This is the third of a series of three articles on Catherine of Siena's spirituality and her political engagement; the first examined
the spirituality guiding such engagement (Villegas 2021a) and the second Catherine's spirituality regarding the crusade (Villegas 2021b).

3.When I refer to Catherine's beliefs, I do not refer primarily to intellectual assent to doctrines, but to that which is held to be true by a person and as such guides their acts and choices. 


\section{Catherine's wisdom on discernment}

As context for reading the instances of Catherine's discernment described in this article, I offer a summary of her wisdom on discernment. ${ }^{4}$ Her central insight is that capacity to perceive and carry out God's will depends on a person's level of transformation in his or her capacity for charity (love). God's will is carried out when we live according to biblical love, namely, with capacity to see and act on behalf of what is for and in the common good. One of Catherine's central images highlights this: discernment is an offshoot of the tree of charity (Catherine of Siena 1980:Chaters 9, 10) (Letter 213). ${ }^{5}$ Capacity for love involves a process of transformation that occurs over time through the dialectical experience of God's merciful, unconditional love in response to recognition of need for God to grow beyond sinfulness, woundedness and selfcenteredness. Transformation of self-centeredness leaves one increasingly free to perceive and carry out God's will.

Catherine also describes the transformation needed for discernment as transformation of desire, by which she means that the depth of a person's motivation and perception, his or her thought, feeling, imagination and all that forms his or her spiritual core, becomes increasingly directed to what is congruent with God's love and truth and thus God's will. When desire is transformed, the directionality of all the energies of the person becomes increasingly congruent with what God wants.

Central to transformed desire is the progressive acceptance that following Jesus entails taking up the cross, as God's will may involve self-denial or suffering. To the extent that one is resistant to undergoing these human experiences, one will be blocked from perceiving and desiring God's will. Accordingly, transformed love makes one capable of embracing suffering. ${ }^{6}$

I will argue that Catherine's application of this wisdom in her own life contributed to both her heroic commitment to God's will and to her unbending interpretations of reality leading to her controversial view of God's will. In addition, Catherine applied the above wisdom in the reproofs detailed below. She reproached Raymond of Capua, William Flete and Giovanni dalle Celle for failure to live up to the

4.Catherine's wisdom on discernment is not found in one treatise but must be culled from passages scattered throughout many of her 383 letters and The Dialogue. She communicated in a non-systematic, literary fashion, using intertwined images and communicated in a non-systematic, literary fashion, using intertwined images and metaphors. Accordingly, thematisation of this wisdom is a complex task. Here I offe a summary of material found in Villegas (1997, 2013:214-224). For another
thematisation of Catherine's basic teaching on discernment, see Mclntosh (2004:54-61).

5.Citations and my translations of Catherine's letters are based on A. Volpato's critical edition of the letters and the Tommaseo (T) numbering used by Volpato (Catherine of Siena 2002). This critical edition does not date the letters, so that here letters wil be cited by number only. Volpato is further annotating his critical edition in an online version (Catherine of Siena 2016), where he offers dating for some of the letters. The best English translation is that of S. Noffke's four-volume work (Catherine of Siena 2000-2008), where letters are published in order of Noffke's dating based on linguistic, textual and historical evidence. Volume 4 has an index at pp. 409-422. For a discussion of letter dating and the different manuscripts of Catherine's letters, see Catherine of Siena (2000-2008:xxvii-I). At the end of this article, I present a table of letters cited with Noffke's dating.

6.For further details about Catherine's wisdom on transformation, see McDermott (2007, 2008; Noffke 1996:11-74; Villegas 2017:5, 6). On Catherine's exhortations on transformation through suffering, see the discussion of $L 333$ to Raymond of Capua below, which is an example of wisdom Catherine repeated in many letters, such as $29,74,252$ and others. transformation she expected of them, thus failing to accomplish God's will. From Catherine's perspective, none had attained the capacity for charity required to act for the good of the church rather than getting caught up in selfcenteredness.

\section{Instances where others diverged from Catherine's discernment} Raymond of Capua's Mission to France

In December 1378, Pope Urban $\mathrm{VI}^{7}$ sent Raymond of Capua (1330-1399) - the Dominican Friar ${ }^{8}$ assigned by ecclesiastical authorities as Catherine's spiritual advisor - on missions to advocate for his papacy with the French. ${ }^{9}$ Twice Raymond returned without completing his missions, which Catherine was certain were God's will. On the first undertaking, Raymond attempted to enter France north of Genoa but turned back when one of his companions was abducted and he learned that assassins were waiting for him on the French side. At Urban's behest, Raymond instead returned to Genoa to preach a war against Clement VII, who had been elected in September 1378 (Catherine of Siena 2000-2008:IV.90, 28, 41; Gardner 1907:291-293). ${ }^{10}$

When Catherine learned about the mission's failure, she wrote to Raymond, reproaching the spiritual immaturity that led him to fail in obedience to the pope and thus accomplishing God's will. ${ }^{11}$ Raymond acted like a self-centred child incapable of love:

You were not even worthy of staying a bit on the field of battle but as a child were chased back, and you gladly fled, and even rejoiced that God should learn of your weakness. (Letter 333$)^{12}$

Raymond should seek growth beyond his selfish self-love to be able to eat bread - like an adult - with the mouth of holy desire and the teeth of love. Catherine wished he could eat mouldy bread (i.e. be willing to suffer). An adult ready to serve God would take the mouldy bread and dip it into the blood of Christ's side to be empowered to suffer for the good of others and, therefore, accomplish God's will:

Dipping the mouldy bread of struggles into this precious blood ... they seek to find a way to offer glory and honour to God; they recognize that in time of great struggle ... they embrace (literally hug) these struggles knowing that in this way they are better transformed to imitate Christ crucified. (Letter 333)

\section{Italian elected in April 1378}

8.See Villegas (2021a:2-3) for a discussion of Raymond's mayor role in Catherine's political involvement and political views. He became her spiritual advisor in 1374.

9.Clement VII (1342-1394), 'anti-pope' residing in Avignon was supported by the French during the schism that began with his election in September 1378.

10.Gardner's work offers still relevant detail not easily found elsewhere regarding Catherine of Siena's political engagement citing her letters extensively; it is acknowledged as a mostly accurate history by contemporary scholars such as Luongo (2012:26).

11.Over time, Catherine became a close friend who challenged Raymond's own spiritual practice (see Coakley 2006:182-183).

12.As stated in note 5 , translations are mine based on A. Volpato's critical edition (Catherine of Siena 2002). The goal of my translations is to offer as literal a rendition of Catherine's style of communication as possible; her graphic, direct, metaphorical communication is significant to her thought. 
Furthermore, Catherine lamented that Raymond was sadly not a grown up of the sort she had hoped him to be, ready for martyrdom if necessary to carry out the pope's mission. She wished he had contributed a stone block to the wall of holy church with your blood [i.e. become a martyr] for love of the Blood!' (Letter 333). In short, Raymond had failed to make the right choice, namely, going on to France risking martyrdom for the good of the church.

On his second mission in May 1379, Raymond was to deliver a Bull to the King of France arguing for Urban VI's legitimacy. This time the trip involved crossing into French territory from Barcelona, with a safe conduct from Cardinal Pedro de Luna, now in Spain. The latter had been a friend of Raymond's and had supported Urban. Unfortunately, when Raymond arrived in Spain, he found that de Luna had changed his allegiance to Clement VII and would not offer safe passage to France. Without safe passage, the trip would risk capture and possible death, so Raymond again returned to Genoa (Catherine of Siena 2000-2008:IV.228; Gardner 1907:316-318).

Catherine again reproached Raymond and expressed her disappointment in him. She couched her critique in concern for his spiritual well-being and a long exhortation about transformation through personal encounter with the Crucified. 'I reprimand you so that you can be your true self and invite God's goodness to lead you to greatest perfection' (Letter 344). Raymond's fear for his life instead of continuing to France was a sign of lack of charity, a relapse to selfish selflove. Raymond relied too much on his own strength, rather than on God's capacity to take care of those pursuing his will:

When I don't love, I don't trust in him [God] but in myself; my servile fear reveals the lukewarm quality of my love and the extent to which the light of faith is blocked, showing that I trust in myself revealing my lack of faith in my creator. In this way tasks that God calls me to carry out and puts in my hands do not come to the fruitful goal begun by God's assignment. ... Am I blocking providence with my unfaithfulness? (Letter 344)

After her exhortations, Catherine directly tells Raymond that he discerned incorrectly; he should have gone to France as requested by Urban VI, 'Christ on Earth'. For the pope's requests are God's will. ${ }^{13}$

I realize you let go of what was burdensome due to weakness. ... To better accomplish God's will and that of Christ on earth, pope Urban VI, I wish you had pursued the route and means that was assigned to you. ... If you couldn't go as a monk, then go as a pilgrim, if not on foot then on all fours, if without money, then begging. This would have been faithful obedience to God. (Letter 344)

To remedy his failure, Raymond should pray to be covered in the blood of Christ that would give him the strength to be faithful to God's plans. Most of all, he should allow God to further transform him so that his desire would become congruent with truth:

13.One of Catherine's beliefs to be discussed here.
I rejoice, and wish you to rejoice as well, that since your desire increases, God will wish to fulfil it, as he welcomes true, holy desires; especially if you open the eye of your intellect with the light of most holy faith, in this manner you will know God's will. (Letter 344)

\section{Raymond's perspective}

Clearly Raymond discerned differently than Catherine. Urban VI understood the predicaments Raymond came up against, as evidenced by the fact he did not reprimand him, but rather offered him alternative missions. In other words, Raymond did not disobey the pope. Common sense would suggest that in both cases Raymond pursued the wise course of action. Losing his life on the way to France would not have advanced Urban VI's cause and the strengthening of his papacy, which Catherine hoped would allow Urban to focus on reform of the church, a cause dear to Catherine's heart and certainly God's will.

\section{Flete and the Council of the Wise}

Convinced that it was God's will to advocate for the papacy of Urban $\mathrm{VI}^{14}$ Catherine went to Rome to be available to work on this, the most impassioned cause of the last year of her life. One of the initiatives she supported and perhaps helped to initiate was the Council of the Wise, which called for select hermits and members of religious orders to intercede for the pope and for some of them to go to Rome to offer wise counsel. ${ }^{15}$ Urban wrote to Bull (1378) requesting this help:

[W] summon to our assistance the devout tears and assiduous prayers of the just children of the Church, that they may humbly and devoutly assail the ears of the Lord, and He may the sooner bend to have compassion upon us. (Cited in Gardner 1907:294)

William Flete, ${ }^{16}$ a contemplative monk, and one of Catherine's mentors and spiritual friends, was one of several monks and members of religious orders to whom Catherine wrote including Urban's Bull - encouraging a response to Urban VI's invitation.

In exhorting Flete and his fellow hermit, Antonio of Nice, to go to Rome, Catherine reminded them to embrace the Cross, a sign of transformation and readiness to follow God's will and serve the church without self-centeredness. She cautioned Flete that he must not stay in the peace and quiet of his hermitage, for this would be a temptation:

Do not seek peace and quiet in anything other than Christ crucified; develop a hunger for the table of the Cross and God's honour, the salvation of persons and the reform of holy church, which is in such need of this reform. ... In truth pursue God's will and that of his vicar [Urban VI]; leave the woods and come into the battlefield. For if you do not do this you will have alienated yourself from the will of God. (Letter 326)

14.Pontificate April 1378-October 1389.

15.See Letter 323 to Bartolomeo Serafini, Carthusian Prior, urging him to find others to go to Rome and to do so with urgency.

16.Cambridge theologian and Augustinian monk who had moved to a monastery outside of Siena to follow a vocation as a hermit; he was known as a holy hermit and valued as a spiritual director. 
Flete, as well as several others, refused Urban's invitation. Catherine was so troubled by this that she would not write to Fleet directly, instead sending her reproach via Antonio:

I didn't expect Brother William [Flete] to answer with such irreverence for holy obedience. ... Obedience to the pope is more perfect, and we should always be subject to his command even onto death [martyrdom]. Even if obedience to the pope might seem to us lacking in discernment ${ }^{17}$ because it deprives us of peace and consolation, we should obey. The contrary, I repeat, involves great imperfection and the deceit of evil. (Letter 328)

Catherine then compared Flete's disobedience with the obedience of two elderly monks who responded to the pope's call as Flete and Antonio should have done. These virtuous monks offered the discomforts of their trip and stayed away from their hermitages for the good of the church. If Flete was going to refuse to go to Rome, he should at least have asked the pope to mission him to remain in his hermitage in this way avoiding sinful disobedience.

\section{Flete's perspective}

Flete remained faithful to his vocation as a contemplative hermit devoted to intercession and to offering spiritual counsel, a vocation that would be disrupted by travel to Rome. Indeed, in his prayer Flete had a vision of Urban VI as true pope. Based on this he contacted English ecclesiastical authorities to argue in favour of Urban VI's papacy (Gardner 1907:298). This sequence of events affirmed that his vocation lay in prayer at his hermitage.

In addition, given the fraught state of papal politics, Urban was unlikely to have followed Fleet's recommendations or those of other monks rather than those of his ecclesiastical and temporal supporters who held positions of power. In other words, Flete's discernment can be interpreted as faithful to his experience of God's guidance.

\section{Florence Interdict (1376-1378)}

Catherine's discernment regarding Gregory $\mathrm{XI}^{\prime} \mathrm{s}^{18}$ interdict over Florence offers another instance where her perception of God's will differed from that of others with committed spiritual journeys. Given the overlap of ecclesiastical and temporal authority in Catherine's day, interdicts - forbidding communities from receiving or offering the sacraments and even other church ministries - were used to exercise political power by enforcing papal authority. While Tuscan City States were independent, they had allegiances with the papacy and were subject to pressure by the pope's mostly French representatives. In 1376, emerging republican philosophies against the secular power of the church were advocated by important Florentines who influenced Florence's adherence to the anti-papal league (Luongo 2006:168). Alarmed by these developments, Gregory XI,

17.Catherine uses the word discrezione, discernment, with more than one meaning One is a reference to the virtue of discernment, that is, the capacity to perceive that which is in right ordered measure, which is the meaning here. A discussion of this virtue and Catherine's multifaceted use of discrezione is discussed in Villegas $(1997: 20,23,24,27,28)$.

18.Pontificate: $1370-1378$ supported by his curia, declared an interdict on Florence from early 1376 to March 1378 - forbidding celebration of the sacraments and closing churches. ${ }^{19}$

Catherine strongly supported the interdict based on her firm belief that the pope, as Christ on earth, must be obeyed and that any deviation from such obedience was a $\sin .{ }^{20}$ She expressed this support in several letters, including one sent to Angelo, Bishop of Florence, praising him for his clear vision of God's will and his courage in carrying it out. She lauded Angelo's persistence in objecting to breaches of the interdict, even going into exile rather than violating God's will by presiding as ecclesiastical authority over priests who violated the interdict. ${ }^{21}$ Catherine wrote to Angelo:

I have the great joy of learning of your perseverance and steadfastness. I pray that even unto deat $h^{22}$ you will not turn back, thus acting as a virtuous man and as one of the sweet smelling flowers of the mystical body of holy church ... I want to see you a manly person, not fearful so that you can better accomplish God's will and my desire for your salvation. (Letter 242)

\section{Opposition to interdict}

Clergy and religious leaders in Florence differed in their acceptance of the interdict. Some known for their wisdom and holiness supported breaching the interdict to offer the sacraments. One of these was Giovanni dalle Celle, one of Catherine's spiritual friends and advisors. ${ }^{23} \mathrm{He}$ was 'renowned for his holiness, wisdom and knowledge of the Scriptures, he converted many young Florentines through his direction and letters' (Introduction to Letter 296, Catherine of Siena 2000-2008:II.532 ). Indeed, Catherine had sent young men to benefit from his counsel. Dalle Celle had a significant following and wrote in support of violation of the interdict for pastoral reasons (Luongo 2006:159, 185).

When Catherine learned that dalle Celle advocated breaching the interdict, she wrote to correct his view regarding God's will, although she is less blunt and direct than with Raymond and Flete, perhaps because Catherine was less close to dalle Celle. Her objections were couched in an exhortation about the importance of receptivity to the suffering required to serve God because without this, God's will cannot be accurately perceived or executed. Catherine informs dalle Celle that she is discouraged by the behaviour of the 'ministers of the blood' [priests]. She asserts, 'my tongue cannot describe so many faults and evils' (Letter 296). The religious and laity amongst the Florentines were equally

19.On the interdict against Florence, see Luongo (2006:167-176, 185-186; Vauchez 2018:48-49, 56-68).

20.See, for instance, Letter 284 where Catherine complains to Cardinal de Luna asserting clerics are preaching heresy encouraging people to receive the sacraments; this is heresy because it violates the pope's command. See also letter 207 to Florentine leaders who are against the interdict.

21.See Noffke's introduction to Letter 242 (Catherine of Siena 2000-2008:II.527).

22.Referring to martyrdom. My emphasis. See Villegas (2021b:3) on martyr spirituality in Catherine.

23.Dalle Celle was a Florentine nobleman who started as a parish priest, but after conversion from a less than exemplary life became a hermit living in Vallombrosa just outside Florence. 
hopeless in obeying the pope regarding the interdict. After her lamentation, Catherine states:

Whether they do this [flaunt the interdict] out of imperfection or because of advice received, if I were the one advising, I would advise that if they want to live perfectly they should choose death [rather than disobey God's will, i.e. flaunt the interdict]; and if they should feel too weak to do so, they should leave the place, which is the cause of $\sin ^{24}$ (Letter 296)

Dalle Celle's view that making the sacraments available and offering pastoral care was more important than obeying the pope's interdicts was more congruent with sacramental theology ${ }^{25}$ and, indeed, more congruent with Catherine's value system regarding the church's role as purveyor of salvation. The fact that in this case Catherine prioritised obedience to the pope in determining God's will shall be interpreted and discussed below in 'Beliefs: Filters for discernment'.

\section{Crusades}

For Catherine, the crusades were clearly God's will. While she was enlisted by ecclesiastical authorities to advocate for this cause, ${ }^{26}$ it was one dear to her heart. Indeed, she wrote over 40 letters encouraging participation in the Crusades, including nine to Gregory XI, urging him to pursue his plans as quickly as possible. She also tried to persuade her followers to join a holy passage pilgrimage (i.e. the crusade). ${ }^{27}$ In addition, she travelled throughout Tuscany to persuade temporal and ecclesiastical authorities to join this cause.

\section{Birgitta of Sweden's advice to Gregory XI}

Yet, another medieval woman mystic and saint who advised ecclesiastical and temporal authorities warned Gregory XI that the crusade was not pleasing to God. Birgitta of Sweden of noble birth, married and widowed - eventually resided in Rome and became a mystical-prophetic advisor to several popes until her death during Gregory XI's pontificate. ${ }^{28}$ Birgitta advised that:

$[A] \mathrm{s}$ for the expedition which the Pope is organizing to redeem the sepulchre of Christ with mercenary soldiers, that will no more please Him than did the worship of the Golden Calf. (Cited in Gardner 1907:101-102)

Furthermore, in her Revelations, Birgitta informs that God is displeased with crusaders' lack of compassion with 'unbelievers' and with their fighting out of pride and greed (Birgitta of Sweden 2006:bk. 2, Chapter 19). In other words, Birgitta, who claimed her wisdom was based on revelations

24.The date and context of the letter make clear that Catherine is referring to the interdict although it is not explicitly named. See also comments by Noffke (Catherine of Siena 2000-2008:II.532)

25.Catholic sacramental thelology-at least since Thomas Aquinas-asserted the importance of the sacraments for salvation.

26.In Villegas (2021a:3-4), I show that the political causes in which Catherine engaged were not initiated by her, that she was enlisted for political purposes by ecclesiastical authorities.

27.Catherine's crusade letters to Gregory XI were analysed in Villegas (2021a:4, 6) and those to other correspondents in Villegas (2021b:3-8).

28.For a description of Birgitta's involvement in advising popes, see Falkeid (2017:135145; Gardner 1907:44-46, 101-105). of words and images received from God, discouraged Gregory XI's crusade.

\section{Giovanni dalle Celle against women pilgrims}

In her passion for the crusade as a path to salvation, an opportunity for martyrdom and an offering pleasing to God, Catherine advised some of her fellow mantellate ${ }^{29}$ to pilgrim to the Holy Land (Letters 132, 144). However, Giovanni dalle Celle advised one of his spiritual daughters, Domitila, not to abandon her convent for dangerous and distant journeys. This was not God's will, he told her, and exhorted her not to let herself be influenced by Catherine. ${ }^{30}$ Dalle Celle's judgement counters Catherine's conviction that her female followers should join the holy passage pilgrimage to the Holy Land.

\section{Urban VI election}

Catherine saw God's will in the election of Urban VI and the work of deceit and evil in the election of Clement VII. ${ }^{31}$ If Urban VI was the true pope, his election was for the good of the church and, therefore, God's will. Accordingly, Catherine wrote multiple letters urging the acceptance of Urban as true pope and admonishing that whoever was against him would be on the side of falsehood and $\sin ^{32}$

While we cannot know whether Catherine's discernment regarding Urban VI's papacy was representative of God's will or not, it is notable that others of holy reputation diverged from her discernment and came to see Clement as the true pope. One was Cardinal de Luna who had initially supported Urban and was reputed as a man of integrity who changed his allegiances in the search for truth. ${ }^{33}$ Another was the Carthusian abbot general Guillaume Rainaud, one of Catherine's correspondents (Letter 55), who first supported Urban and then changed his allegiance to Clement. ${ }^{34}$ Most significantly, Saint Vincent Ferrer, a learned Dominican university professor and itinerant preacher, known for his holiness, supported Clement VII and his friend de Luna. Indeed, Ferrer worked for the support of the Avignon papacy while seeking to resolve the schism in the church (Ferreiro 1998:41-42; Gardner 1907:284).

\section{Analysis}

We have seen that persons with commitments to a relationship with God and the good of the church came to judgements that diverged from those of Catherine and their judgements 29.Women belonging to the penitentiary lay order to which Catherine belonged.
Under Dominican direction, these women did not take vows.

30.Dalle Celle's letter is cited in Viglione (2014:95)

31.For example, Catherine affirms 'he [Urban VI] is true pope, in whom are entrusted the keys of the Blood [salvation]' (Letter 347). By contrast, Catherine refers to Clement VII as 'the anti-pope, devil incarnate' (Letter 322).

32.See Letter 310 to three cardinals who changed their allegiance to Clement VII. Other letters include 312, 313, 317, 322, 347 and 357 (not an exhaustive list).

33.See Noffke's introduction to Letter 284 (Catherine of Siena 2000-2008:III.114; see also Gardner 1907:257).

34.Guillaume had collaborated inviting clerics to Urban's Council of the Wise; see section on Flete. 
were more likely to be congruent with God's will. Flete and Raymond made ordered personal discernments. Those who prioritised offering the sacraments during the Florence interdict followed a more theologically and pastorally accurate path. Birgitta's revelations about Gregory XI's crusade seem to better reflect wisdom and truth, for Gregory XI's crusade never flourished, and the original religious fervour for a holy passage pilgrimage of the early crusades had waned, as Birgitta rightfully pointed out. While judgements about the relative 'right order' regarding the papacies of Urban VI versus that of Clement VII are difficult to make, what is relevant here is that persons with exemplary spiritual journeys, including a saint, differed from Catherine's absolute clarity.

How, then, can we interpret the fact that Catherine came to controversial and probably inaccurate discernments? For, by the time Catherine offered her discernment on papal politics she had journeyed long on the path to union with God and transformation of desire, the transformation central to Catherine's wisdom regarding capacity to perceive and carry out God's will.

\section{Beliefs: Filters for discernment}

I propose that Catherine's deeply held beliefs about what she considered paramount truths became filters through which she interpreted God's will. These beliefs and the absolute, unbending manner in which she held and applied them in some cases resulted in controversial discernments. In the following paragraphs, I examine these beliefs and the manner in which they influenced Catherine's judgements.

\section{Role of church and pope in salvation}

In the first of this series of articles I showed that salvation was a guiding truth for Catherine's mission on behalf of papal politics. She was uncompromisingly convinced that the church as an institution and the pope as its head mediated salvation. The pope was Christ on earth irrespective of his personal holiness so that his decisions regarding church policy were God's will and must be understood as for the good of the church. ${ }^{35}$ She affirms this in various letters including the following one to the Florentines:

You know well that Christ left us his Vicar for the salvation of our souls. We can only obtain salvation in the mystical body of Holy Church whose head is Christ and we the members. Whoever disobeys Christ on earth [the pope], who is in the place of Christ in heaven, will not partake of the blood of the Son of God. For God has ordained it so that through his [the pope's] hands this blood and all the Holy Church's sacraments which receive life through the blood - should be given to us. (Letter 207)

Accordingly, obedience to the pope was an ultimate value and disobedience a serious sin:

35.See Villegas (2021a:4-6) for a discussion of Catherine's belief regarding the salvific role of the pope as Christ on earth; this article extensively shows Catherine's belief in salvation as paramount value.
Whoever rebels against the church and our Christ on earth [the pope] - is a rotten member who has fallen into the side of death; for whatever we do to him [the pope] we do to Christ on earth. (Letter 207)

That Catherine's belief in obedience to the pope for the good of the church was of ultimate importance and that she applied it in an absolute, unbending manner is evidenced by the fact that it trumped other beliefs important to her. Catherine speaks often about the blood of Christ as a symbol of his life given for us and attests in many letters and The Dialogue ${ }^{36}$ to the significance of the Eucharist. As just cited above, she affirms that the sacraments - mediators of the salvific blood are essential for salvation. It is, therefore, remarkable that while she showed compassion for the Florentines left without the sacraments, ${ }^{37}$ she believed priests who violated the interdict to offer these were sinning by disobeying the pope and therefore going against God's will.

\section{Martyrdom}

Another overarching, foundational belief that coloured Catherine's discernments was the ideal of martyrdom. As the ultimate sign of giving of oneself to God and of imitation of Jesus' dying for us, she was convinced that the desire for martyrdom and the willingness to die as a martyr were God's will. As we saw, this ideal had caught Catherine's imagination early on in her journey and continued influencing her thought until her death. ${ }^{38}$

Catherine's belief in the church as the mediator of salvation, the pope as Christ on earth and martyrdom as the highest of ideals undergirds her certainty about God's will in several of the situations analysed in this article. Raymond should have gone to France at all costs because the pope ordered it for the good of the church, and he should have been willing to risk his life, that is, become a martyr. Flete should obey the pope's invitation to go to Rome, which was also for the good of the church and as such a greater good than Flete's interpretation about his contemplative vocation. The Florence interdict was God's will because it was Gregory XI's policy for the good of the church in cementing church authority and moving towards peace.

\section{Crusade}

Catherine's absolute conviction that the crusade was God's will was also undergirded by several of her central beliefs. Catherine would have been formed by preaching about the salvific nature of the crusades. ${ }^{39}$ Indeed, from Catherine's

36.There is a long treatise on the Eucharist, the body of Christ, in Catherine of Siena (1980:ch. 110-112).

37.On Catherine's compassion for the Florentines, see Letter 207 and Luongo (2006:166).

38.See Letter 226 to Raymond. See Villegas (2021b) where I show that elements of martyr spirituality are present in a majority of her letters.

39.Based most likely on Bernard of Clairvaux's sermons, which had great influence on early crusade theology and spirituality. Bernard argued that the 'holy passage' (crusade) was God's will, so much so that if a crusade were unsuccessful it was because of the sinfulness of the crusaders and not an error in the pope's call for because of the sinfulness of the crusaders and not an error in the pope's call for
such a holy pilgrimage (Flood 1974:26, 35). Note that Bernard wrote 200 years before Catherine's day in a different historical context. 
perspective the crusade offered salvation - a primordial value - in many ways. It was an opportunity for the salvation of soldiers of European lands who would stop fighting against each other, for Catherine saw as sinful war amongst European 'brothers'. ${ }^{40}$ Furthermore, soldiers would find transformation through the crusade pilgrimage to the Holy Land. In fighting to recover the places where Jesus lived and died, the possibility of conversion would be offered to 'unbelievers'. ${ }^{41}$ In addition, the crusade offered an opportunity for martyrdom as a goal of this holy passage pilgrimage. And, of course, the crusade represented the pope's policy for the good of the church and was, therefore, unquestionably God's will.

\section{Foundational belief}

In the letters analysed, we saw that Catherine held her beliefs in an absolute, unbending manner. Once she was convinced that something was true, that truth became an unquestioned guiding value. Context seemed irrelevant to her. A major reason for the absoluteness with which Catherine held these and other beliefs she considered true and therefore God's will undoubtedly had to do with the manner in which she experienced her relationship with God. She lived the wisdom she taught, in that she acted as someone persuaded of the intimacy of her union with God so that if she understood something to be true then it must be guided by God.

One could say, then, that Catherine had a foundational belief that functioned as an overarching first filter for all her discernments, both those that were prophetic in calling ecclesiastical and temporal authorities to behaviours and policies that promoted salvation and those described in this article, which were contested by others and could be interpreted as not representative of God's will. This foundational belief was her unquestioned assurance about the depth of her relationship with God. Catherine acted as someone profoundly persuaded of Paul's own belief, 'for I have been crucified with Christ; and it is no longer I who live, but it is Christ who lives in me' [my emphasis] (Gl 2:19-21, NRSV).

This assurance is evidenced in the unequivocal certainty with which she communicated about what she considered God's will. She - a young, uneducated lay woman - told both lay and ecclesiastical authorities that she was right and they were wrong. ${ }^{42}$ She claimed in many such instances to speak for God himself. For instance, to Queen Giovanna of Naples she stated, 'I ask and press on behalf of Christ crucified' [my emphasis] (Letter 138). She told Gregory XI:

I beg you in the name of Christ crucified, I want you to offer this mercy ... I demand mercy for them, I say to you, sweet Christ on earth, on behalf of Christ in heaven ... [my emphases] (Letter 196)

40.See, for instance, Letter 235 to the King of France, and Letter 140 to a mercenary soldier.

41.See, for instance, Letter 374 to a knight she was persuading to join the crusade.

42.For instance, see the discussion of letters 133 and 143 to Queen Giovanna of Naples and Letter 235 to King Charles V of France in Villegas (2021b:6-7) and various letters to Pope Gregory XI in Villegas (2021a:5-9).
This self-assurance about being in tune with God's will in matters related to the good of the church, however, led to an unbending interpretation of these truths, which in the instances analysed here resulted in controversial discernments.

\section{Personality and culture: Influences on discernment}

\section{Tendency to the absolute and heroic}

The above overarching filter was intertwined with Catherine's personality characteristics and sociocultural context. Catherine was drawn in an unnuanced manner to heroic spiritual values. From her childhood she longed to imitate the martyrs and was attracted to those idealised holy persons who lived alone in the desert and those who were said to practise extreme penances and severe fasts for love of God. While these legends of spiritual heroism were undoubtedly part of the popular spirituality of her day, Catherine had a penchant for taking these literally and tried to live them. She escaped as a child to a cave - to be a hermit - and then lived in solitude in her own home while practising physical penances and severe fasting. While in the Tuscany of the late 14th century a spirituality of martyrdom formed part of pious formation, the ideal invited persons to be willing to give their life to God - in service, not literally - and be willing to suffer in order to serve God's church. Yet Catherine interpreted martyr spirituality literally, personally desired to die as a martyr, ${ }^{43}$ and invited her followers and correspondents - including the most worldly and least pious - to have a similar desire. ${ }^{44}$

I propose this attraction to heroic ideals, which persisted until Catherine's death, contributed to the absoluteness with which she held beliefs, especially her ideal of martyrdom and the supremacy of belief in obedience to the pope: two beliefs which are present in the examples examined here. Thus, her understanding of Raymond's and Flete's disobedience of the pope reflected a highly idealistic and absolute view of such obedience. As we saw, neither Raymond nor Flete interpreted their choices as disobedience to the pope; neither did Florentine clerics or the devout monk dalle Celle, who believed offering the sacraments was more important than obedience to the papal interdict. Her belief in the crusade was highly idealised, as evidenced both in her expectation that her followers - including single women - would go on a crusade pilgrimage, and in her lack of appreciation of the political realities in Europe that made a crusade impracticable at that time. The expectation that her followers and correspondents would be persuaded to seek martyrdom in a crusade pilgrimage was also highly idealistic, indeed, quite unrealistic.

43.For instance, Catherine expresses her deep disappointment to Raymond, 'my desire to give my life for the truth and for the sweet bride of Christ [the church] was not fulfilled', when the Florentines rebelling against the interdict attacked a house not fulfilled, when the Florentines rebelling against the interdict attacked a house where Catherine was staying, and she was spared death (Letter 295). For a
discussion of this incident, see Luongo (2006).

44.See the analysis of Catherine's crusade letters where she invites persons as disparate as the Queen of Naples, professional warriors, a worldly enemy of the Papal states and others, to desire martyrdom and go on crusade and seems to expect this invitation would be accepted (Villegas 2021b). 


\section{Lack of formal education and worldly experience}

Catherine's lack of formal education and worldly experience are sociocultural factors, which also influenced her discernment. ${ }^{45}$ In the case of the crusade, these factors may in part account for the contrast between Catherine's discernment and that of Birgitta of Sweden. Birgitta had a breadth of experience that Catherine did not have. As a Swedish noblewoman, she received an education; she was married and had children. She had personally dealt with temporal and church authorities and had been on pilgrimage within Europe and to the Holy Land. Birgitta's education and experience of ecclesiastical and temporal politics could have made her receptive to critical views of papal policy and specifically of the crusades. Similarly, Raymond's, Flete's and dalle Celle's nuanced understanding of obedience to the pope and their realistic ability to analyse the political and practical circumstances about which they discerned were grounded in their education and intimate knowledge of the workings of the church. ${ }^{46}$ Similar qualities would apply to the monks and ecclesiastical authorities mentioned above who did not a priori judge the election of Clement VII as 'evil' and could consider him the legitimate pope.

\section{Conclusion}

Catherine's wisdom on discernment has biblical roots in the teachings of Paul as noted above. As we are transformed in Christ, we are better able to perceive and carry out God's will. Undoubtedly this wisdom on discernment makes a significant contribution to Christian practice. The above analysis, however, shows that even a person as fully transformed as Catherine, someone as exceptional in her complete openness to God dwelling within her and uncompromisingly desirous of doing God's will could misperceive or misinterpret this will. This vulnerability suggests that Catherine's wisdom regarding discernment must be modified by conscious attention to contextual influences. We are all limited and sinful and therefore vulnerable to misinterpretations; even the most holy mystic is vulnerable to personality and contextual influences in the interpretation of even the most sublime spiritual experience - for interpretation of the Spirit's movement within us is filtered through our human reality, which includes our profoundest beliefs. Indeed, beliefs deeply root the way we seek to uncover the transcendent meaning of our lives, and the practices we pursue on this journey of discovery and growth. ${ }^{47}$ And beliefs are in turn coloured by our personality, our culture and our time in history. This suggests discernment calls not only for awareness of our level of transformation following Catherine's wisdom - but also for conscious consideration of our beliefs and awareness of our personalities and cultural contexts.

45.Suzanne Noffee, expert Catherinian scholar, suggests Catherine was naïve regarding politics. The lack of education and worldly experience together with a highly idealistic personality are congruent with this characterisation (Noffke 1996:55).

46. Raymond was a theologian and canon lawyer, Flete a theologian from Cambridge University and dalle Celle a Florentine nobleman and ordained priest.

47.See the definition of spirituality in Villegas (2018:2), which highlights that spirituality is guided by beliefs.
Letter numbers followed by dates according to S. Noffke (Catherine of Siena 2000-2008)

$55 \quad$ September 1377

132 December 1375

144 July 1375

196 February 1376

$207 \quad$ April 1376

213 October 1378

242 October 1377

$284 \quad$ April 1378

295 June 1378

296 October 1377

310 September 1378

322 December 1378

326 December 1378

328 January 1379

333 January 1379

$344 \quad$ August 1379

347 May 1379

\section{Acknowledgements Competing interests}

The author declares that she has no financial or personal relationships that may have inappropriately influenced her in writing this article.

\section{Author's contributions}

D.L.V. is the sole author of this research article.

\section{Ethical considerations}

This article followed all ethical standards for research without direct contact with human or animal subjects.

\section{Funding information}

This research received no specific grant from any funding agency in the public, commercial or not-for-profit sectors.

\section{Data availability}

Data sharing is not applicable to this article as no new data were created or analysed.

\section{Disclaimer}

The views and opinions expressed in this article are those of the author and do not necessarily reflect the official policy or position of any affiliated agency of the author.

\section{References}

Birgitta of Sweden, 2006, The revelations of St. Birgitta of Sweden, B. Morris (ed.), transl. D.M. Searby, Oxford University Press, Oxford.

Catherine of Siena, 1980, The dialogue, transl. S. Noffk (ed.), Paulist, New York, NY.

Catherine of Siena, 2000-2008, The letters of Catherine of Siena, transl. S. Noffke (ed.), 4 vols., Arizona Center for Medieval and Renaissance Studies, Tempe, AZ. 
Catherine of Siena, 2002, Lettere, A. Volpato (ed.), in Caterina da Siena: Opera Omnia, CD-ROM, Provincia Romana dei Frati Predicatori, Pistoia. PDF of Lettere available online, http://centrostudicateriniani.it/it/santa-caterina-da-siena/scritti.

Catherine of Siena, 2016, Lettere, edizione critica e commento, A. Volpato (ed.), Centro internazionale di studi cateriniani, Rome. http://www.centrostudicateriniani.it/ en/st-catherine-of-siena/writings.

Coakley, J.W., 2006, Women, men, and spiritual power: Female saints and their male collaborators, Columbia University Press, New York, NY.

Falkeid, U., 2017, The Avignon papacy contested: An intellectual history from Dante to Catherine of Siena, Harvard University Press, Cambridge, MA.

Ferreiro, A., 1998, 'Vincent Ferrer's beati Petri apostoli: Canonical and apocrypha sources in popular vernacular preaching', Harvard Theological Review 91(1), 41-57. https://doi.org/10.1017/S001781600000643X

Flood, B., 1974, 'St Bernard's view of crusade', Cistercian Studies 9(1), 22-35.

Gardner, E.G., 1907, Saint Catherine of Siena: A study in the religion, literature, and history of the fourteenth century in Italy, J.M. Dent \& Co., E.P. Dutton \& Co., London.

Luongo, F.T., 2006, The saintly politics of Catherine of Siena, Cornell University Press, Ithaca, NY.

Luongo, F.T., 2012, 'The historical reception of Catherine of Siena', in C. Muessig, G. Ferzoco \& B.M. Kienzle (eds.), A companion to Catherine of Siena, pp. 23-45, Brill, Leiden.

McDermott, T., 2007, 'Catherine of Siena's teaching on self-knowledge', New Blackfriars 88(1018), 637-648. https://doi.org/10.1111/j.1741-2005.2006. 00130.x/
McDermott, T., 2008, Catherine of Siena: Spiritual development in her life and teaching, Paulist, New York, NY.

McIntosh, M.A., 2004, Discernment and truth, Herder \& Herder, New York, NY.

Noffke, S., 1996, Catherine of Siena: Vision through a distant eye, Liturgical, Collegeville, MN. Reprint edition, Scholars Press, 2006.

Vauchez, A., 2018, Catherine of Siena: A life of passion and purpose, transl. M.F. Cusato, Paulist, Mahwah.

Viglione, M., 2014, 'Esigenza di pace, prospettive di missione e idea di crociata nelle lettere di Santa Caterina da Siena', Revue d'Histoire Ecclésiastique 109(1-2), 91-122. https://doi.org/10.1484/J.RHE.1.103886/

Villegas, D.L., 1997, 'Discernment in Catherine of Siena', Theological Studies 58(1), 19-38. https://doi.org/10.1177/004056399705800102

Villegas, D.L., 2013, 'Catherine of Siena's wisdom on discernment and her reception of scripture', Acta Theologica 32(2S), 209-227. https://doi.org/10.4314/actat.v32i2S.12/

Villegas, D.L., 2017, 'Continuous prayer in Catherine of Siena', HTS Teologiese Studies/ Theological Studies 73(3), a6411. https://doi.org/10.4102/hts.v73i3.4611/

Villegas, D.L., 2018, 'Spirituality and belief: Implications for study and practice of Christian spirituality', HTS Teologiese Studies/Theological Studies 74(3), a5037. https://doi.org/10.4102/hts.v74i3.5037/

Villegas, D.L., 2021a, 'Catherine of Siena's spirituality of political engagement', HTS Teologiese Studies/Theological Studies 77(2), a6319. https://doi.org/10.4102/hts. v77i2.6319

Villegas, D.L., 2021b, 'Catherine of Siena's crusade letters: Spirituality and political context', HTS Teologiese Studies/Theological Studies 77(2), a6499. https://doi. org $/ 10.4102 /$ hts.v77i2.6499 